\title{
Studi Tentang Peranan Variabel Kompetensi, Penilaian Kinerja, dan Kondisi Kerja Terhadap Perwujudan Kepuasan Kerja Guru
}

\author{
Didit Darmawan', Rahayu Mardikaningsih², Samsul Arifin ${ }^{3}$, Ella Anastasya \\ Sinambela ${ }^{4}$, Arif Rachman Putra ${ }^{5}$ \\ 1,2,3,4,5 Universitas Mayjen Sungkono, Indonesia \\ *e-mail: dr.diditdarmawan@gmail.com
}

\begin{abstract}
Job satisfaction is the main indicator for the survival of a teacher in a relationship with his school. Job satisfaction felt by teachers will have an impact on students, co-workers, and leaders. Work results are also affected by the level of teacher job satisfaction. This study will analyze the effect of competence, performance appraisal and working conditions on teacher satisfaction. The research was conducted in Pasuruan Regency and the research subjects were teachers in secondary schools. The analytical tool used is multiple linear regression analysis. The findings show that competence has a significant effect on teacher job satisfaction. Performance appraisal has a significant effect on teacher job satisfaction. Working conditions have a significant effect on teacher job satisfaction. The three independent variables show a simultaneous significant effect on teacher job satisfaction.
\end{abstract}

Keyword: Competence, Performance Appraisal, Working Conditions, Job Satisfaction.

\begin{abstract}
Abstrak: Kepuasan kerja adalah indikator utama untuk bertahannya seorang guru menjalin hubungan dengan sekolahnya. Kepuasan kerja yang dirasakan guru akan memberikan dampak kepada siswa, rekan kerja, dan pimpinan. Hasil kerja juga terpengaruh oleh tingkat kepuasan kerja guru. Penelitian ini akan menganalisis pengaruh kompetensi, penilaian kinerja dan kondisi kerja terhadap kepuasan guru. Penelitian dilakukan di Kabupaten Pasuruan dan subjek penelitian adalah guru-guru di sekolah tingkat menengah. Alat analisis yang digunakan adalah analisis regresi linier berganda. Hasil temuan menunjukkan bahwa kompetensi berpengaruh signifikan terhadap kepuasan kerja guru. Penilaian kinerja memiliki pengaruh signifikan terhadap kepuasan kerja guru. Kondisi kerja berpengaruh signifikan terhadap kepuasan kerja guru. Ketiga variabel bebas menunjukkan pengarh yang signifikan secara simultan terhadap kepuasan kerja guru.
\end{abstract}

Kata Kunci: Kompetensi, Penilaian Kinerja, Kondisi Kerja, Kepuasan Kerja.

Copyright (c) 2021 The Authors. This is an open access article under the CC BY-SA 4.0 license (https://creativecommons.org/licenses/by-sa/4.0/)

\section{PENDAHULUAN}

Tugas-tugas seorang guru adalah tugas profesional dimana tugas-tugas tersebut hanya dapat dikerjakan dengan kompetensi khusus yang diperoleh melalui program pendidikan. Seorang guru harus mempunyai kompetensi untuk melaksanakan tugasnya diantaranya kompentesi mengajar yang harus dimiliki guru adalah kemampuan mengajar, kemampuan memotivasi siswa dan kemampuan 
mengembangkan suasana kelas. Selain itu, kompentensi kepemimpinan yaitu kemampuan guru untuk merencanakan, kemampuan teknis dan kemampuan untuk berhubungan, serta memahami orang lain. Selain itu kemampuan memberi dukungan yang mengacu pada kecakapan ketangkasan visual dan manual. Dengan adanya kompetensi guru menggerakkan potensi yang ada pada siswa, ini sangat menentukan terhadap kualitas hasil belajar yang dapat dicapai untuk kegiatan belajar (Arifin et al., 2017).

Kompetensi dapat diartikan sebagai pengalaman, pengetahuan, keterampilan dan sikap yang diperoleh selama hidup untuk kinerja yang efektif dalam tugas atau pekerjaan (Bernsteiner et al., 2013). Pendapat lain menyatakan bahwa kompetensi adalah konsep pengetahuan, keterampilan dan sikap seseorang (Spencer dan Spencer, 1993). Kompetensi guru sebagai anggota suatu organisasi sekolah mengarah kepada batasan spesifik dan empiris fitur perilaku yang mengarah pada pencapaian hasil kerja yang sukses (McLagan, 1989). Dengan demikian, organisasi yang menghadapi berbagai tantangan perubahan lingkungan harus lebih kompetitif dan mempertahankan statusnya didasarkan pada kompetensi individu yang akan mengarah pada peningkatan prestasi dan hasil kerja (Dubois, 2010). Selain itu, kompetensi seseorang dapat menentukan seberapa baik hasil pekerjaannya dan seberapa puas terhadap pekerjaannya. Hal ini berdasarkan studi dari Kong et al. (2012) yang menyatakan bahwa kompetensi memiliki hubungan yang signifikan dengan kepuasan kerja.

Pelaksanaan tugas utama guru tidak dapat dipisahkan dari kompetensi guru dalam penguasaan pengetahuan, penerapan pengetahuan dan keterampilan sesuai amanat Peraturan Menteri Pendidikan Nasional Nomor 16 Tahun 2007 tentang Standar Kualifikasi Akademik dan Kompetensi Guru. Menurut Peraturan Menteri Negara Pendayagunaan Aparatur Negara dan Reformasi Birokrasi Nomor 16 Tahun 2009, penilaian kinerja guru adalah penilaian dari tiap butir kegiatan tugas utama guru dalam rangka pembinaan karir, kepangkatan dan jabatannya. Penguasaan kompetensi dan penerapan pengetahuan serta keterampilan guru, sangat menentukan tercapainya kualitas proses pembelajaran atau pembimbingan peserta didik dan pelaksanaan tugas tambahan yang relevan bagi sekolah, khususnya bagi guru dengan tugas tambahan tersebut. Penilaian kinerja adalah 
komponen penting dari serangkaian praktik sumber daya manusia yang lebih luas merupakan mekanisme untuk mengevaluasi sejauh mana kinerja setiap karyawan sehari-hari terkait dengan tujuan yang ditetapkan oleh suatu organisasi (Coutts dan Schneider, 2004).

Penilaian kinerja juga dikenal sebagai formal, sistem struktur dan evaluasi karyawan yang terkait dengan tanggung jawab pekerjaan mereka (Mondy dan Mondy, 2014). Namun, hasilnya adalah untuk menemukan segala sesuatu tentang kinerja karyawan saat ini di tempat kerja dan kemudian mereka dapat meningkatkan tingkat kinerja mereka secara lebih efektif di masa depan (Dessler, 2013). Akibatnya, dapat bermanfaat bagi karyawan, serta organisasi dan masyarakat juga (How, 2011). Menurut Atiomo (2000) menyatakan bahwa penerapan dari penilaian kinerja berkaitan dengan beberapa hal seperti kompensasi, identifikasi kebutuhan pelatihan, meningkatkan kinerja karyawan, meningkatkan komunikasi dan motivasi, dan berkontribusi untuk meningkatkan tingkat kepuasan kerja karyawan. Studi Hariani et al. (2019); Syah et al. (2018); Harkat (2014); Brown (2010); Addison (2007); dan Poon (2004) menunjukkan adanya hubungan yang signifikan antara penilaian kinerja dan kepuasan kerja.

Kondisi kerja telah menjadi faktor penting untuk menentukan secara langsung kepuasan seorang anggota organisasi dan kinerjanya (Mardikaningsih, 2016). Pada hakekatnya setiap pekerja memiliki kondisi kerja yang berbeda sehingga nantinya akan menumbuhkan adaptasi dan kondisi yang berbeda pula. Di tempat kerja, mereka bekerja sama dengan teman sekerja dengan berbagai macam harapan yang pada umumnya berbeda pula prioritasnya (Darmawan, 2015). Untuk menciptakan kondisi kerja yang baik perlu didukung dengan adanya komunikasi, motivasi dan partisipasi bawahan untuk pengambilan keputusan demi kepentingan organisasi. Pimpinan harus menjaga kondisi kerja yang baik melalui kepemimpinannya karena perilaku pemimpin termasuk juga determinan dari suatu kondisi kerja (Arifin et al., 2019). Kepemimpinan yang baik akan mengarah kepada kondisi kerja yang kondusif. Kondisi kerja mendukung pekerjaan dan terjadi minimalisasi gangguan yang berasal darinya dapat menyebabkan munculnya kepuasan kerja bagi para guru. Beberapa studi telah membuktikan bahwa kondisi kerja memberikan peran yang signifikan terhadap kepuasan kerja (Bakotić dan 
Babić, 2013; Newsham et al., 2009; dan Kinzl et al., 2005).

Untuk kehidupan organisasi, kepuasan kerja biasanya sebagai petunjuk tentang kematangan dan keberhasilan organisasi. Salah satu penyebab adanya kondisi kerja yang kurang baik adalah tingkat kepuasan kerja yang rendah (Gunawan, 2015). Sementara itu tingkat kepuasan kerja yang dirasakan oleh kebanyakan anggota organisasi dapat dijadikan gambaran bahwa manajemen organisasi berjalan secara efektif dan telah dikelola dengan baik (Mahyanaila, 2016). Dengan demikian, kepuasan kerja dapat dianggap sebagai cara pandang terhadap pekerjaannya. Ada beberapa hal yang memengaruhi terbentuknya kepuasan kerja seperti kondisi kerja, rekan kerja, pimpinan, gaji, tunjangan, kebijakan-kebijakan dan lain sebagainya (Kreitner dan Kinicki, 2014).

Dengan demikian, penilaian kinerja akurat serta kondisi di tempat kerja yang baik dengan arti sehat, tenang, tentram serta didukung dengan kompetensi yang maksimal dilakukan berdasarkan kesadaran masing-masing anggota organisasi maka mendorong mereka untuk bekerja lebih bersemangat yang pada akhirnya membantu untuk menerapkan rencana dan pekerjaan dengan lebih baik. Berdasarkan latar belakang masalah yang telah penulis kemukakan maka rumusan masalah penelitian ini adalah apakah kompetensi, penilaian kinerja dan kondisi kerja berpengaruh signifikan secara parsial dan simultan terhadap kepuasan kerja guru?

\section{METODE}

Tujuan penelitian ini mengetahui apakah terdapat pengaruh kompetensi, penilaian kinerja dan kondisi kerja terhadap kepuasan kerja guru. Jenis penelitian ini adalah eksplanatory. Penelitian ini bermaksud untuk mendeskrisikan keberadaan hubungan kausal yang terjadi serta melakukan uji keterkaitan antar variabel. Populasi penelitian ini adalah guru SMP Negeri di Kecamatan Gempol Kabupaten Pasuruan yang berjumlah 105 orang dari tiga sekolah negeri. Sedangkan sampel penelitian adalah guru yang berjumlah 21 orang atau $20 \%$ dari total populasi. Dengan demikian cara pengambilan sampel didasarkan pada teknik acak. Pada penelitian ini telah ditetapkan bahwa kompetensi (X.1), penilaian kinerja (X.2), kondisi kerja (X.3) adalah sebagai variabel bebas, sedangkan kepuasan kerja guru 
(Y) sebagai variabel terikat. Berikut ini rincian dari variabel-variabel penelitian. Kompetensi (X.1) adalah kemampuan guru untuk bekerja baik kemampuan intelektual maupun kemampuan pisik.

Adapun indikator kompetensi kerja adalah penguasaan materi pelajaran yang baik, keaktifan guru saat mengajar, penyampaian materi pelajaran yang mudah dipahami oleh siswa, kemampuan untuk mengerti dan memahami tugas yang diberikan, kemampuan membuat keputusan yang berhubungan dengan pekerjaan, mengembangkan solusi alternatif dan merekomendasikan serta memilih tindakan yang tepat. Penilaian kinerja (X.2) adalah upaya untuk melakukan evaluasi dan penilaian hasil kerja seseorang untuk meningkatkan produktivitas dan mengidentifikasi masalah-masalah pekerjaan. Penilaian kinerja terdiri dari lima indikator, yaitu supervisor, rekan kerja, komite penilaian, penilaian mandiri, bawahan dan $360^{\circ}$ feedback sebagai kolaborasi penilaian yang dilakukan oleh atasan, bawahan, rekan kerja, diri sendiri dan komite penilaian. Kondisi kerja (X.3) merupakan suatu sarana atau tempat yang sangat berperan untuk kegiatan-kegiatan organisasi. Indikatornya adalah fasilitas dan perlengkapan, suasana kerja termasuk hubungan antar rekan kerja dan atasan.Variabel terikat adalah kepuasan kerja (Y) merupakan suatu respon efektif atau emosional yang mengarah kepada berbagai tampilan dari suatu pekerjaan. Artinya memungkinkan seseorang puas terhadap unsur pekerjaannya tetapi tidak puas dengan unsur yang lainnya. Indikatornya adalah kondisi kerja yang kondusif, terpenuhinya kebutuhan fisiologis, terciptanya hubungan sosial yang baik, terpenuhinya kebutuhan akan penghargaan, kesesuaian pekerjaan dengan bakat dan kemampuan, dan promosi pekerjaan bagi yang berprestasi.

Pengumpulan data dengan melakukan penyebaran kuesioner. Skala penilaian yang digunakan pada kuesioner adalah skala likert dengan rentang nilai 18 (Sangat Setuju sekali=8, Sangat Setuju=7, Setuju=6, Cukup Setuju=5, Kurang Setuju=4, Tidak Setuju=3, Sangat Tidak Setuju=2, Sangat Tidak Setuju Sekali=1). Teknik analisis menggunakan analisis linier berganda dengan dua variabel bebas dan satu variabel terikat. Setelah pengumpulan data maka dilakukan uji reliabilitas dan validitas data. Selanjutnya dilakukan uji asumsi klasik yang terdiri dari uji normalitas, uji autokorelasi, uji heterokedastisitas dan uji multikolonieritas. Uji 
kelayakan data dilanjutkan dengan uji hipotesis yang terdiri dari uji t dan uji F.

\section{HASIL DAN PEMBAHASAN}

\section{Hasil}

Tahap awal adalah uji validitas untuk mengetahui akurasi item pertanyaan menampung setiap pernyataan responden. Item pertanyaan yang valid ditetapkan dengan batas berpedoman pada nilai corrected item total correlation yang lebih besar dari 0,3. Tabel 1 menunjukkan semua item pernyataan memiliki nilai melebihi 0,3 sehingga setiap item pertanyaan dinyatakan valid.

Tabel 1. Uji Validitas

\begin{tabular}{lccccccc}
\hline Variabel & 1 & 2 & 3 & 4 & 5 & 6 & 7 \\
\hline Kompetensi (X.1) & 0,409 & 0,564 & 0,473 & 0,491 & 0,331 & 0,435 & 0,421 \\
\hline Penilaian kinerja (X.2) & 0,593 & 0,473 & 0,558 & 0,338 & & & \\
\hline Kondisi Kerja (X.3) & 0,437 & 0,412 & 0,427 & 0,472 & 0,436 & 0,313 & \\
\hline Kepuasan Kerja (Y) & 0,368 & 0,541 & 0,351 & 0,411 & 0,474 & 0,428 & \\
\hline
\end{tabular}

Sumber : Output SPSS

Tabel 2 menunjukkan uji reliabilitas. Uji reliabilitas digunakan untuk mengetahui sejauh mana alat pengukur dapat dipercaya dengan membandingkan nilai alpha dengan batas nilai 0,6. Berdasarkan Tabel 2 diketahui bahwa semua variabel dinyatakan reliabel.

Tabel 2. Uji Reliabilitas

\begin{tabular}{lcc}
\hline Variabel & Nilai Alpha & Status \\
\hline Kompetensi (X.1) & 0,605 & Reliabel \\
\hline Penilaian kinerja (X.2) & 0,667 & Reliabel \\
\hline Kondisi Kerja (X.3) & 0,703 & Reliabel \\
\hline Kepuasan Kerja (Y) & 0,722 & Reliabel
\end{tabular}

Sumber : Output SPSS

Uji selanjutnya adalah uji asumsi klasik. Pertama adalah uji autokorelasi. Deteksi autokorelasi dilakukan dengan menggunakan metode Durbin-Watson. Dari hasil output SPSS diketahui nilai DW sebesar 1,897 yang menunjukkan bahwa tidak ada masalah autokorelasi.

Selanjutnya uji multikolinearitas yang dideteksi melalui nilai toleransi dan nilai VIF. Pada Tabel 3 nilai VIF antara 1 dan 10 dan nilai toleransi yang diperoleh 
kurang dari 1 maka dapat dikatakan bahwa persamaan suatu model penelitian tidak menunjukkan adanya gejala multikolinearitas.

Tabel 3. Uji Multikolinieritas

\begin{tabular}{ccc}
\hline \multirow{2}{*}{ Model } & \multicolumn{2}{c}{ Collinearity Statistics } \\
\cline { 2 - 3 } & Tolerance & VIF \\
\hline Kompetensi (Y) & 0,625 & 1,211 \\
\hline Penilaian kinerja (X2) & 0,718 & 1,325 \\
\hline Kondisi Kerja (X3) & 0,751 & 1,529
\end{tabular}

\section{Sumber : Output SPSS}

Pada Tabel 3 terlihat bahwa nilai toleransi yang didapatkan adalah kurang dari 1 dan nilai VIF antara 1 dan 2. Berdasarkan hal tersebut dinyatakan model regres tidak ada masalah multikolinieritas. Variabel bebas tersebut tidak saling berkorelasi di antara variabel-variabel bebas pada model regresi.

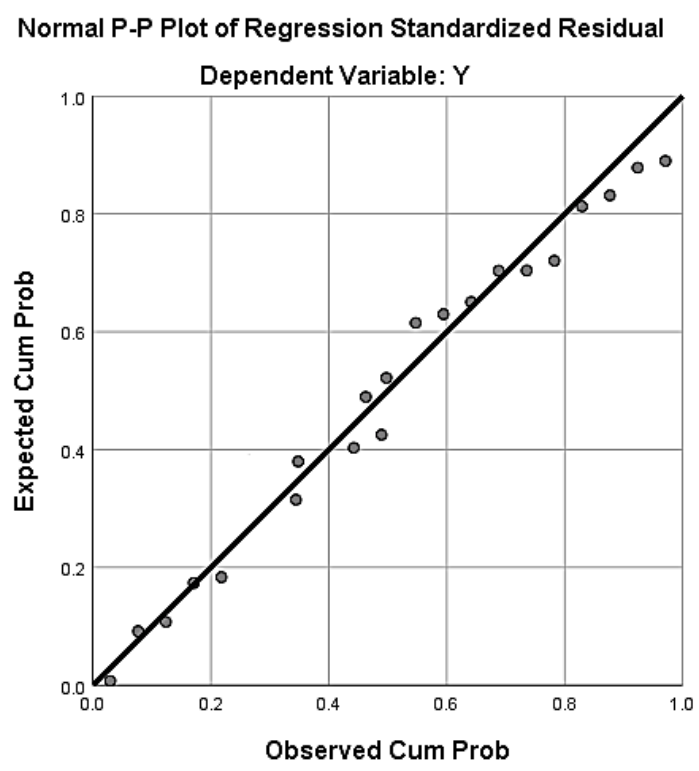

Gambar 1. Uji Normalitas

Selanjutnya adalah uji normalitas untuk mengetahui apakah data yang ada terdistribusi normal atau tidak, secara konvesional dapat dilihat dari grafik sebaran normal dari data yang ada. Hasil uji normalitas data menggunakan analisis grafik yaitu grafik normal P-plot seperti pada Gambar 1 menunjukkan titik-titik menyebar di sekitar grafis diagonal. Penyebaran titik-titik tersebut searah garis diagonal sehingga dapat dikatakan data memiliki distribusi normal. 
Tabel 4. Uji t

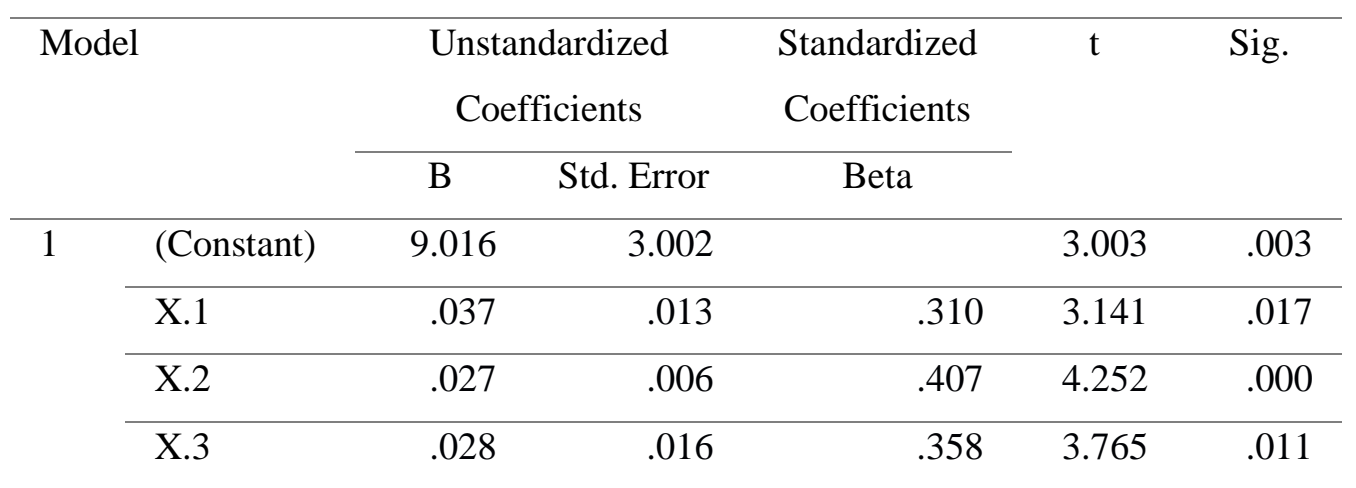

Sumber : Output SPSS

Setelah uji asumsi klasik akan dilakukan uji hipotesis yaitu uji t. Tabel 4 menunjukkan hasil dari uji t. Secara parsial variabel kompetensi, penilaian kinerja dan kondisi kerja memiliki pengaruh yang signifikan terhadap kepuasan kerja dengan signifikan $<0,05$. Nilai signifikan masing-masing variabel telah memenuhi syarat di bawah 0,05 maka model regresi yang terbentuk adalah : Y = 9,016+ 0,037X.1 + 0,027X.2 +0,028X.3. Konstanta sebesar 9,016 menyatakan bahwa jika tidak ada kompetensi, penilaian kinerja dan kondisi kerja maka kepuasan kerja sebesar 9,016. Koefisien regresi kompetensi sebesar 0,037 menyatakan bahwa setiap penambahan satu poin kompetensi akan meningkatkan kepuasan kerja sebesar 0,037. Koefisien regresi penilaian kinerja sebesar 0,027 menyatakan bahwa setiap penambahan satu poin penilaian kinerja akan meningkatkan kepuasan kerja sebesar 0,027. Koefisien regresi kondisi kerja sebesar 0,028 menyatakan bahwa setiap penambahan satu poin kondisi kerja akan meningkatkan kepuasan kerja sebesar 0,028 .

Tabel 5. Uji F

\begin{tabular}{llrrrrr}
\hline Model & & $\begin{array}{c}\text { Sum of } \\
\text { Squares }\end{array}$ & \multicolumn{1}{c}{ df } & \multicolumn{1}{c}{$\begin{array}{c}\text { Mean } \\
\text { Square }\end{array}$} & F & Sig. \\
\hline 1 & Regression & 2,765 & 3 &, 781 & 11.760 & $.000^{\mathrm{b}}$ \\
\cline { 2 - 7 } & Residual & 2,464 & 17 &, 149 & & \\
\cline { 2 - 7 } & Total & 5,229 & 20 & & & \\
\end{tabular}

Sumber : Output SPSS

Berdasarkan Tabel 5 hasil output SPSS ANOVA diperoleh F hitung adalah 11,760 dengan tingkat signifikansi sebesar 0,000. Probabilitas tersebut lebih kecil dibandingkan dengan 0,05 sehingga model regresi dapat dipakai untuk 
memprediksi variabel kepuasan kerja. Variabel kompetensi, penilaian kinerja dan kondisi kerja secara simultan berpengaruh signifikan terhadap kepuasan kerja. Sementara itu koefesien determinasi diperoleh nilai sebesar seperti pada Tabel 6 berikut ini.

Tabel 6. Koefesien Determinasi

\begin{tabular}{rrrrrr}
\hline Model & R & R Square & \multicolumn{1}{c}{$\begin{array}{c}\text { Adjusted R } \\
\text { Square }\end{array}$} & $\begin{array}{r}\text { Std. Error of } \\
\text { the Estimate }\end{array}$ & \multicolumn{1}{c}{$\begin{array}{c}\text { Durbin- } \\
\text { Watson }\end{array}$} \\
\hline 1 & $.518^{\mathrm{a}}$ & .269 & .246 & 2.52257 & 1,897 \\
\hline
\end{tabular}

Sumber : Output SPSS

Nilai Adjusted R square menjadi 0,246 yang berarti variabel kompetensi, penilaian kinerja dan kondisi kerja memberikan kontribusi sebesar 24,6\% terhadap pembentukan kepuasan kerja. Sementara itu ada 75,4\% keterlibatan dari faktorfaktor lain di luar penelitian ini.

\section{Pembahasan}

Berdasarkan hasil analisis data diperoleh pernyataan bahwa variabelvariabel bebas dipenelitian ini terbukti memiliki pengaruh yang signifikan terhadap kepuasan kerja guru. Temuan pertama menyatakan kompetensi yang dimiliki oleh guru memiliki pengaruh signifikan terhadap kepuasan kerja guru. Temuan ini sejalan dengan temuan dari Nikolajevaite dan Sabaityte (2016). Kompetensi guru memungkinkan sekolah mencapai visi dan misi melalui kontribusi dari hasil kerjanya. Dengan kepribadian dan perilaku, pengetahuan dan keterampilan yang sesuai untuk melakukan tugas akan menghasilkan kinerja lebih optimal (Darmawan, 2013).

Kompetensi guru yang terbentuk dari pengalamannya akan berimplikasi terhadap peningkatan kualitas kerja para guru. Oleh karena itu, tidak hanya berfokus pada kompetensi pedagogik tetapi kompetensi guru juga tertuju pada kompetensi yang menunjukkan kepribadian yang baik, kompetensi yang mampu berinteraksi dengan semua personil di sekolah dan kompetensi yang mampu menunjukkan sikap profesional sebagai guru. Oleh karena itu, kompetensi utama adalah yang paling terkait dengan kepuasan kerja, pimpinan dapat memperhatikan kompetensi khusus kepada guru-guru muda di mendatang karena kompetensi terbukti memengaruhi kepuasan kerja atau ketidakpuasan, ketidakbahagiaan di tempat kerja. Menurut Brain (2002), konsekuensi dari pengabaian hal penting itu 
terhadap pekerjaan dapat memunculkan kualitas kerja yang buruk, absensi, dan diberhentikannya guru karena ketidakmampuan.

Temuan kedua menyatakan bahwa penilaian kinerja berpengaruh signifikan terhadap kepuasan kerja guru. Temuan ini didukung oleh hasil penelitian dari Hariani et al. (2019); Syah et al. (2018); Harkat (2014); Brown (2010); Addison (2007); dan Poon (2004). Penilaian kinerja sebagai proses efektif dan alat manajemen sumber daya manusia yang paling penting dimana penilai digunakan untuk mengevaluasi kinerja guru dan melalui ini, guru dapat puas dengan deskripsi pekerjaan mereka diorganisasi. Penilaian kinerja dapat mengukur keakuratan kinerja guru dan akan membantu untuk membangun hubungan antara kinerja pada tugas dan memiliki potensi yang jelas untuk penghargaan diorganisasi.

Tingginya kualitas penilaian kinerja dimaksudkan untuk meningkatkan tingkat kepuasan kerja seorang guru. Sementara itu, kualitas pengalaman penilaian kinerja yang rendah dapat mengakibatkan tingkat kepuasan kerja yang lebih rendah dimana mereka merasa bahwa konstribusi mereka kepada organisasi tidak dihargai karena kapasitas mereka terbatas untuk melakukan kontrol proses dan mengalami kebingungan tentang harapan kinerja organisasi. Dengan demikian, penilaian kinerja adalah alat yang sangat diperlukan untuk sebuah organisasi di mana pimpinan memberikan lebih banyak informasi bagi guru pada platform pengambilan keputusan mengenai berbagai aspek personel seperti pengembangan karir, dan peningkatan prestasi. Jadi, membantu mereka untuk memainkan peran penting dalam penilaian kinerja dimana pimpinan mudah untuk mengevaluasi kinerja pekerjaan mereka.

Selain itu, seorang pimpinan juga harus memiliki pemahaman yang mendalam tentang kriteria standar kinerja, hal tersebut akan memberikan mereka pengetahuan tentang bagaimana kinerja guru akan diukur diorganisasi. Mereka juga harus mengetahui standar kinerja untuk setiap posisi yang tersedia diorganisasi yang dapat membantu mereka untuk mengharapkan kualitas dari guru dan juga dapat berkomunikasi secara efektif kepada guru yang terlibat. Penilaian kinerja yang dilakukan secara efektif akan meningkatkan kepuasan kerja selanjutnya memotivasi guru dalam bekerja. Elemen motivasi yang paling memberikan 
pengaruh besar terhadap kepuasan kerja adalah imbalan (Terera dan Ngirande, 2014).

Dengan demikian pendapatan para guru akan mengarahkan kepada kepuasan kerja tetapi hal tersebut tidak dapat begitu saja disikapi dengan kebijakan pimpinan karena sekolah negeri terkait dengan kebijakan pemerintah daerah dan pusat. Sertifikasi guru setidaknya dapat menunjang pendapatan yang secara rutin telah diterima oleh guru. Selain itu bentuk motivasi lainnya adalah peluang pelatihan dan pengembangan dapat menjadi beberapa faktor lain yang berkontribusi terhadap kepuasan kerja guru. Pimpinan dapat memilih guru yang memiliki potensi berkembang di masa mendatang untuk mengikuti pelatihan kerja.

Temuan ketiga menyatakan bahwa kondisi kerja berpengaruh signifikan terhadap kepuasan kerja guru. Temuan ini sesuai dengan temuan Bakotić dan Babić (2013); Newsham et al. (2009); dan Kinzl et al. (2005). Kondisi kerja adalah faktor ekstrinsik yang melibatkan sumber daya konkret dan aturan kerja. Kondisi kerja memberikan kontribusi kepada psikologis karyawan (Antony dan Valadez, 2002). Kondisi kerja adalah faktor kunci untuk memengaruhi kepuasan kerja bahkan mengarah pada keterlibatan yang lebih tinggi, komitmen tingkat tinggi atau memilih untuk meninggalkan pekerjaan. Menurut Mardikaningsih et al. (2017), pada umumnya turunnya kepuasan seorang guru karena ketidakpuasan guru yang berhubungan dengan finansial maupun unsur non finansial.

Untuk mewujudkan kepuasan guru maka kebutuhan dasar mereka harus terpenuhi seperti pendapatan layak dan pemberian insentif yang terarah. Selain itu adanya kesempatan dan peluang untuk mengembangkan diri terkait dengan kompetensi kerja dan keberadaan kondisi kerja yang membuat aman dan nyaman dalam bekerja serta fasilitas yang menyenangkan dan sebagainya (Palembeta dan Arifin, 2014.). Dengan langkah-langkah demikian maka diharapkan tingkat kepuasan guru dapat tercapai. Implikasi dari konsep kepuasan kerja tertuju pada beragam aspek dari perilaku organisasi (Darmawan, et al. (2020). Kondisi sebaliknya juga demikian dan organisasi menghindari kemunculan dari ketidakpuasan karena memungkinkan terjadinya ketidakefektifan diorganisasi.

\section{SIMPULAN}


Penelitian ini menemukan bahwa kompetensi, penilaian kinerja dan kondisi kerja memiliki pengaruh yang signifikan secara parsial dan simultan terhadap kepuasan kerja guru. Berdasarkan hal tersebut beberapa saran yang dapat diajukan oleh penulis adalah sebagai berikut. Pertama kompetensi dapat ditingkatkan melalui pelatihan kerja maupun pemberian tugas-tugas baru untuk menambah kompetensi. Pelatihan kerja selain berorientasi pada kompetensi pedagogik, juga berorientasi pengembangan keperibadian, kemampuan berinteraksi secara sosial dan sikap profesionalme.

Pimpinan perlu juga memperhatikan kesejahteraan para guru terkait dengan faktor finansial maupun non finansial. Hubungan kerja antar guru dan kepada atasan sangat diperlukan untuk tetap kondusif agar kondisi kerja memunculkan kepuasan kerja. Selain itu hubungan kerja, ketersediaan fasilitas yang lengkap juga diperlukan untuk terbentuknya mendorong efektivitas program kerja yang dilakukan organisasi. Kondisi kerja yang tidak nyaman akan memengaruhi kepuasan kerja guru. Pimpinan harus menentukan sikap untuk mengurangi kondisi kerja yang tidak nyaman agar para guru tidak mengalami stres di tempat kerja.

\section{DAFTAR RUJUKAN}

Addison, J. T. (2007). The Determinants of Performance Appraisal Systems: A Note (Do Brown and Heywood's Results for Australia Hold Up for Britain?). Discussion Paper No.306.

Antony, J. S., \& Valadez, J. R. (2002). Exploring the Satisfaction of Part-time College Faculty in the United States. Review of Higher Education, 26, 41-56

Arifin, S., A. R. Putra, \& C. F. Budi. (2019). Pengaruh Kompetensi, Kompensasi dan Kepemimpinan terhadap Kinerja Karyawan, Ekonomi, Keuangan, Investasi dan Syariah, Vol. 1, No. 1 September, 23-32

Arifin, Samsul. R. Mardikaningsih \& Y. R. Al Hakim. (2017). Pengaruh Kedisiplinan, Kompetensi, dan Motivasi Kerja terhadap Kinerja Karyawan, Management \& Accounting Research Journal, Vol.2 No.1 November, 43-50

Atiomo A.C. (2000). Human Resource Management; Malthouse Management Science Books, Lagos.

Bakotić, Danica \& Tomislav Babić. (2013). Relationship between Working 
Conditions and Job Satisfaction: The Case of Croatian Shipbuilding Company, International Journal of Business and Social Science, Vol. 4 No. 2; February 2013, 206-213

Bernsteiner, R., Mirski, P.J., Zangerl, T., \& Groth, A. (2013). Competency management as a basis for further education in the workplace. Inted 2013 Proceedings, 6085-6092.

Brain, C. (2002). Advanced psychology: Applications, issues and perspectives. Cheltenham: Nelson Thornes

Brown, M. (2010). Consequences of the performance appraisal experience. Research Paper. Emerald Group Publishing Limited. 39 (3), 375-396.

Coutts, L. M. \& Schneider, F. W. (2004). Police officer performance appraisal systems: How good are they? Policing: An International Journal of Police Strategies \& Management, 27 (1): 67-81.

Darmawan, D. (2015). Peranan Motivasi Kerja, Kedisiplinan, dan Lingkungan Kerja terhadap Kinerja Guru SD di Kecamatan Gempol Kabupaten Pasuruan, Jurnal Ilmiah Manajemen Pendidikan Indonesia, Vol.1 No.3 Maret, 113-122

Darmawan, D. (2013). Prinsip-Prinsip Perilaku Organisasi, Pena Semesta Surabaya

Darmawan, D et al. (2020). The Quality of Human Resources, Job Performance and Employee Loyalty, International Journal of Psychosocial Rehabilitation, Vol. 24 Issue 3, 2580-2592

Dessler, Gary. (2013). Human Resource Management. 13th edition. Edinburg Gate, Harlow Essex, England: Pearson Education Limited.

Dubois, D.D. (2010). Competency-based human resource management. Nicholas Brealey Publishing

Gunawan, Aditya. (2015). Perilaku Organisasi. Gramedia, Jakarta

Hariani, M., S. Arifin \& A. R. Putra. (2019). Pengaruh Iklim Organisasi, Pengalaman Kerja dan Motivasi Kerja terhadap Komitmen Kerja Karyawan, Management \& Accounting Research Journal, Vol.3 No.2 Mei, 22-28

Hariani, M., M. Irfan \& F. N. J. Souisa. (2019). Pengaruh Penilaian Kinerja dan Komitmen Organisasi terhadap Kepuasan Kerja Penyuluh Pertanian, Ekonomi, Keuangan, Investasi dan Syariah, Volume 1, Nomor 1, September, 30-36 
Harkat, Avisena. (2014). Pengaruh Presepsi atas Reward dan Penilaian Kinerja terhadap Kepuasan Kerja dan Komitmen Pegawai Negeri Sipil (PNS) di Pemerintahan Kabupaten Lumajang. Jurnal Ilmiah INOVASI.Vol.14, No.2, $182-190$

How, Tan Kwang. (2011). Human Resource Management in Malaysia, Theory \& Practice. Syahalam, Malaysia: McGraw-Hill (Malaysia).

Kinzl, J. F., Knotzer, H., Traweger, C., Lederer, W., Heidegger, T., \& Benzer, A. (2005). Influence of Working Conditions on Job Satisfaction in Anesthetists. British Journal of Anesthesia, 94(2), 211-215

Kong, H., Cheung, C., \& Song, H. (2012). From hotel career management to employees' career satisfaction: The mediating effect of career competency. International Journal of Hospitality Management, 31(1), 76-85.

Kreitner, Robert \& Angelo Kinicki. (2014). Perilaku Organisasi, Edisi 9, Salemba Empat, Jakarta

Mahyanaila, R. (2016). Manajemen. Addar Press, Jakarta

Mardikaningsih, R., S. Arifin, A. R. Putra, \& M. Hariani. (2017). The Effect of Motivation and Work Commitment on The Performance of Agricultural Extension Agents, Jurnal Agrimas, Vol.1 No.2 Desember, 115-124

Mardikaningsih, R. (2016). Variabel Kepemimpinan dan Lingkungan Kerja serta Pengaruhnya terhadap Kinerja Karyawan, Management \& Accounting Research Journal, Vol.1 No.1 November, 55-62

McLagan, P.A. (1989). Models for HRD practice. Alexandria, VA: American Society for Training and Development.

Mondy, R. Wayne, Mondy, \& Judy Bandy. (2014). Human Resource Management. 13th edition. Edinburg Gate, Harlow Essex, England: Pearson Education Limited.

Newsham, G., JayBrand, C. D., Veitch, J., Aries, M., \& Charles, K. (2009). Linking Indoor Environment Conditions to Job Satisfaction. Building Research \& Information, 37(2), 129-147

Nikolajevaite, Margarita \& Egle Sabaityte. (2016). Relationship Between Employees' Competencies and Job Satisfaction: British and Lithuanian Employees, Psychology Research, November, Vol. 6, No. 11, 684-692 
Palembeta, Thoriq \& S. Arifin. (2014). Pengaruh Penilaian Kinerja terhadap Motivasi Kerja, Jurnal Ilmiah Manajemen Pendidikan Indonesia, Vol.1 No.1 September, 23-32

Poon, J. M. (2004). Effects of performance appraisal politics on job satisfaction and turnover intention. Emerald, Vol. 33 No. 3, 2004, 13.

Robbins Stephen P. \& Judge Timothy A., (2015). Perilaku Organisasi, Edisi 16, Salemba Empat, Jakarta

Spencer, L.M., \& Spencer, S.M. (1993). Competence at work. NY: Wiley.

Syah, Haikal, Auzan., M. Syaharudin., \& Budi Nurhadjo. (2018). Pengaruh Pengembangan Karier dan Penilaian Kinerja terhadap Kepuasan Kerja melalui komitmen kerja Karyawan Koperasi Agrobisnis Tarutama Nusantara Jember. E-Journal Ekonomi Bisnis dan Akuntansi, 2, 158-163

Terera, S. R. \& Ngirande, H. (2014). The Impact of Rewards on Job Satisfaction and Employees Retention. Mediterranean Journal of Social Sciences. 5(1), $481-487$

Wexley Kenneth N. \& Gary A. Yukl. (2003). Organizational Behaviour and Personnel Psychology. Rineka Cipta, Jakarta 